Johnson, S; (2011) Has the closure of psychiatric beds gone too far? No. BMJ , 343, Article d7410. 10.1136/bmj.d7410

\title{
ARTICLE
}

\section{Has the closure of psychiatric beds gone too far? No.}

\author{
Sonia Johnson, \\ Professor of Social and Community Psychiatry, University College London, \\ Consultant Psychiatrist, Camden and Islington NHS Foundation Trust
}

(Pre-submission and final editing version of Johnson, S. (2011). Has the closure of psychiatric beds gone too far? No. BMJ,343.) Based on the debate with Peter Tyrer Maudsley Debates.

Four ideas, each flawed, underpin views that bed closure has gone too far in the UK. These are, first, that inpatient provision is now meagre, second, that community care policies result in high levels of antisocial behaviour and failure to sustain community living, third, that inpatient wards are an environment conducive to addressing the major problems associated with severe mental illness, and, fourth, that we have exhausted potential strategies for reducing reliance on beds. I will challenge each of these ideas in turn.

Bed numbers have declined steadily since the mid-1950s. At 60.6 beds per 100,000 population, recent WHO figures place UK provision in the middle of the European range, which extends from 10.6 per 100,000 in Italy to 180.1 in Belgium; Germany, Sweden, Denmark and Spain are among the countries with fewer beds than the UK (1). Our rates of involuntary admission are fairly high in international context (2). Current bed use levels in the UK are thus unremarkable.

The second idea, that deinstitutionalisation has unleashed a cohort of mentally ill people who are a threat to others and incapable of sustaining acceptable community functioning, is familiar from the media. Homicides perpetrated by the mentally ill however remain very rare, the most recent data suggesting a declining rate (3). With an adequate resettlement budget, former long-stay patients have not tended to become street homeless or to perpetrate violence (4), and recent findings on homelessness among inpatients suggest it is no more prevalent than in past decades (5). Most people with significant mental illnesses live peaceful lives in the community most of the time, many achieving reasonable subjective well-being despite considerable adversities (6).

Third, it is doubtful whether acute wards, whose main function is now containment of immediate risk (7), are good environments for addressing the most significant problems that people with severe mental illnesses face. These include very low rates of employment (8), poor physical health leading to early deaths (9), high rates of drug misuse (10), and pervasive experiences of social isolation and stigma (11). Many might also benefit from earlier intervention in serious disorders of all types, and from more acceptable and individually tailored treatments to which they are content to adhere. In most of these areas, sustained improvements in outcomes are likelier to be achieved through more effective longterm support and treatment in community settings, where social networks can also be involved when appropriate, than through brief interventions in an institutional environment (12). Admission may even exacerbate long-term difficulties, for example through attrition of coping skills, loss of employment and community tenure, greater exposure to illicit substances, or traumatic experiences in hospital (13). Wards are thus a questionable part of the service system in which to concentrate resources if we can avoid it, especially given their unpopularity with many patients (7). The share of resources devoted to them remains considerable: in $2008,45 \%$ of the NHS mental health budget was dedicated to inpatient care (7). 
Fourth, the evidence suggests that potential strategies for reducing the current pressure on the inpatient mental health system have not been exhausted. With regard to alternatives to acute admission, the major NHS investment has been in crisis resolution teams, now operating throughout England. These can, where well implemented, reduce admission, shorten hospital stays and achieve good satisfaction (14). However, the extent to which these outcomes have been realised in practice varies greatly (15), not surprisingly given that the model is inadequately specified and consistency is thus lacking in how it is implemented. We need now to get this model right nationwide to ensure that the large investment made in it is repaid. Research on community residential alternatives such as crisis houses suggests that these can substitute for hospital for some patients and allow early discharge for others, with relatively low costs and high levels of satisfaction (16). Their availability remains patchy, however, as does that of acute day hospitals and short stay admission wards, two other models with some supporting evidence as means of avoiding or curtailing some hospital stays $(16,17)$. A further preventable drain on inpatient resources is delayed discharge due to unresolved social difficulties.

Joint crisis cards, which are advance agreements with patients about the management of future crises, are one of the few interventions to have shown evidence of reducing compulsory admissions, but are not yet widely used (18). Further back along the pathway to admission, interventions to reduce relapse that have proved effective in trials but are not extensively implemented include family intervention in schizophrenia (19) and a range of structured self management and relapse prevention planning strategies, for example in bipolar disorder (20). At service level, early intervention teams, which deliver good quality psychosis care with a strong social recovery focus, have been effective in reducing relapse and admissions while patients are on their caseloads, but these positive effects dissipate following transfer to standard services (21): can we extend these benefits and reduce bed use through longer exposure to this way of working for selected patients?

Thus returning to a higher level of psychiatric bed provision would, in the current climate of scarcity, be both profligate and pointless. Let us instead dedicate the limited resources we have to improving the quality of existing inpatient services and increasing their acceptability to patients, and to implementing as fully as we can the knowledge that we already have about how reliance on inpatient services may be reduced.

Acknowledgement: I am grateful to Justin Needle and Brynmor Lloyd-Evans for helpful input to this paper.

\section{References}

1. World Health Organisation Regional Office for Europe. (2011) European Health for All Database. http://data.euro.who.int/hfadb/ Accessed November 112011.

2. Salize HJ, Dressing H (2004) Epidemiology of involuntary placement of mentally ill people across the European Union. British Journal of Psychiatry 184: 163-168.

3. Appleby L, Kapur N, Shaw J, Hunt I, Flynn S, While D et al (2011) National Confidential Inquiry into Suicide and Homicide by Mentally III Persons: Annual Report England, Wales and Scotland.

http://www.medicine.manchester.ac.uk/mentalhealth/research/suicide/prevention/nci/i nquiryannualreports/Annual Report July 2011.pdf Accessed November 112011.

4. Leff JP (2001) Why is care in the community perceived as a failure? British Journal of Psychiatry 179: 381-383 
5. Tulloch AD, Fearon P, David AS (2011) Timing, prevalence, determinants and outcomes of homelessness among patients admitted to acute psychiatric wards. Social Psychiatry and Psychiatric Epidemiology Epub ahead of print.

6. Slade, M. (2010) Mental illness and well-being: the central importance of the positive psychology and recovery approaches. BMC Health Services Research 10:26

7. Holloway F, Lloyd IS (2011) Inpatient treatment. In Thornicroft G, Szmukler, G, Mueser KT, Drake RE (Eds.) Oxford Textbook of Community Mental Health. Oxford: Oxford University Press.

8. Marwaha S, Johnson S, Bebbington P, Stafford M, Angermeyer MC, Brugha T et al (2007) Rates and correlates of employment in people with schizophrenia in the UK, France and Germany. Br J Psychiatry 191: 30-37.

9. Osborn DP, Levy G, Nazareth I, Petersen I, Islam A, King MB (2007) Relative risk of cardiovascular and cancer mortality in people with severe mental illness from the United Kingdom's General Practice Research Framework. Arch Gen Psychiatry 62: 242-249.

10. Carrà G, Johnson S (2009) Variations in rates of comorbid substance use in psychosis between mental health settings and areas in the UK: a systematic review. Soc Psychiatry Psychiatr Epidemiol 44: 429-447.

11. Thornicroft G (2006) Shunned: discrimination against the mentally ill. Oxford: Oxford University Press.

12. Thornicroft G, Tansella M, Becker T, Knapp M, Leese M, Schene A et al. (2004) The personal impact of schizophrenia in Europe. Schizophrenia Research 69: 125-132.

13. Bowers L., Chaplin R, Quirk A., Lelliott P. (2009) A conceptual model of the aims and functions of acute inpatient psychiatry. Journal of Mental Health 18: 316-325.

14. Johnson S, Nolan F, Pilling S, Sandor A, Hoult J, McKenzie N, White IR, Thompson $\mathrm{M}$, Bebbington $\mathrm{P}(2005)$ Randomised controlled trial of acute mental health care by a crisis resolution team: the North Islington Study. BMJ 331:599

15. National Audit Office (2007). Helping People through Mental Health Crisis: the Role of Crisis Resolution and Home Treatment Teams. 2007; London: National Audit Office.

16. Johnson S, Lloyd-Evans B, Howard L, Osborn DP, Slade M (2010). Where next with residential alternatives to admission? Br J Psychiatry, 197, s52- s54.

17. Kallert T, Priebe S, McCabe R, Kiejna A, Rymaszewska J, Nawka P, Ocvár L, Raboch J, Stárková-Kalisová L, Koch R, Schützwohl M. (2007) Are day hospitals effective for acutely ill psychiatric patients? A European multicenter randomized controlled trial. J Clin Psychiatry. 68: 278-87.

18. Henderson C, Flood C, Leese M, Thornicroft G, Sutherby K, Szmukler G (2004) Effect of joint crisis plans on use of compulsory treatment in psychiatry: single blind randomized controlled trial. BMJ Jul 17329 (7458). 
19. Berry K, Haddock G (2008) The implementation of the NICE guidelines for schizophrenia: Barriers to the implementation of psychological interventions and recommendations for the future. Psychology and Psychotherapy: Theory, Research and Practice, 81, 419-436

20. Mueser KT, Gingerich S (2011) Illness self-management programmes. In Thornicroft G, Szmukler, G, Mueser KT, Drake RE (Eds.) Oxford Textbook of Community Mental Health. Oxford: Oxford University Press.

21. Gafoor R, Nitsch D, McCrone P, Craig TK, Garety PA, Power P, McGuire P. (2010) Effect of early intervention on 5-year outcome in non-affective psychosis. $\mathrm{Br} \mathrm{J}$ Psychiatry. 196: 372-6. 